\title{
Audit Committee and Financial Performance of Listed Firms in Nigeria
}

\author{
Nse Umoh-Daniel ${ }^{1}$, Beauty Ekiomado Eguasa (Ph.D) $)^{2}, \&$ Best-Okwu, Excellence ${ }^{3}$ \\ ${ }^{1}$ Department of Accounting, Faculty of Social and Management Sciences, Benson Idahosa University \\ ${ }^{2,3}$ Department of Accounting, Faculty of Social and Management Sciences, Benson Idahosa University
}

\begin{abstract}
The broad objective of this study is to examine the impact of Audit Committee (AC) characteristics on the financial performance of listed consumer goods companies in Nigeria. The research sample comprises of eighteen (18) consumer goods companies and secondary data was generated from the annual accounts and reports which spanned from $2010-2019$ financial years. Using the panel regression analysis; the study found that frequency of $\mathrm{AC}$ meetings, independence of $\mathrm{AC}$ and $\mathrm{AC}$ size have significant effect on financial performance. The study concluded that the presence of audit committee is vital in companies. The study therefore recommended that compliance with respect to audit committee size, meetings and independence should be adequately checked to ensure conformity.
\end{abstract}

Keywords: Audit Committee characteristics, financial performance

\section{INTRODUCTION}

$\mathrm{T}$ he Audit Committee (AC) is a central element of corporate monitoring which can enhance the quality of financial reporting through open, candid communication and working relationship with the company's board of directors, internal auditors and external auditors (Mustafa, 2012). Undeniably, the existence of an appropriately constituted Audit Committees is now a necessity for all listed companies in Nigeria (Corporate Governance Code, 2010) with corporate governance regulation placing significant importance on the role of Audit committee. Audit committees (AC) have been widely recommended around the world as an important mechanism for improving the quality of the company's financial reports (Blue Ribbon Committee, 1999). AC is an important and necessary monitoring mechanism widely used in worldwide corporate organizations to monitor the financial reporting process and strengthen corporate governance (Wallace, 2003). Enofe, Aronmwan and Abadua (2013) posit that in order to improve the quality of financial statements, the Audit Committee was constituted. In recent times, the AC responsibilities have become cumbersome amid growing expectation for the AC to play a greater role as the ultimate guardian of investor's interests and ensure corporate financial performance (Atrill, 2006).

Financial performance has implications to organization's health and ultimately its survival. The Firms' management effectiveness and efficiency in making use of company's resources is highly reflected by high financial performance and this in turn contributes to the country's economy at large (Naser \& Mokhtar, 2004). Company performance is very essential to management and other stakeholders such as shareholders, debt holders and the government as it is an outcome which has been achieved by an individual or a group of individuals in an organization related to its authority and responsibility in achieving the goal legally, not against the law and conforming to the morale and ethic (Iswatia, \& Anshoria, 2007). A growing stream of research suggests that Audit Committee characteristics are critically important to the role of improving corporate financial performance.

The role of Audit Committees in affecting firm performance has been argued from several perspectives. Firstly, there is the argument that the opportunistic tendency of managers to engage in unethical practice is reduced in the presence of effective Audit Committee structure. They ensure corporate conformance with investors' and society's interests and expectations by limiting the abuse of power, the siphoning-off of assets, the moral hazard, and the wastage of corporatecontrolled resources and several other variants of the agency problem. Simultaneously, they establish the means to monitor managers' behavior to ensure corporate accountability. Secondly, there is also the argument that audit committees creates a more diverse resource pool that is able to make decisions based on the evaluation of more. Hence Audit Committees bring advantages to the entity, such as broader perspectives in decision making, higher creativity and innovation, and successful marketing to different types of customers. (Carter, Simkins \& Simpson 2003).

Furthermore, the Audit Committee play this role of ensuring sustainable financial performance of the company by overseeing the firm's financial reporting process, including the integrity of financial statements, the effectiveness of internal controls and the monitoring of both internal and external auditors. They also enhance the board of director's capacity to act as a monitor of management by providing more detailed knowledge and understanding of financial statements of the company (Mohammad, 2015). Audit Committee ensures judicious and prudent management of resources and the preservation of resources of the corporate organization. In the process of ensuring ethical and professional standards and the pursuit of corporate objectives, it seeks to ensure customer satisfaction, high employee morale and the maintenance of market discipline, which eventually results in corporate stability and improve financial performance (Ojeka, SIyoha, \& Obigbemi, 2013; Okoi, Stephen \& Sani, 2014). 
Furthermore, an examination of some of the attempts at identifying the nature of the relationship between Audit Committee and financial performance showed mixed findings in the literature. Ojeka, Iyoha and Obigbemi (2014) which explores the influence of Audit Committee effectiveness on firm's performance. The result of the analysis showed a positive significant relationship between independence and financial expertise of the Audit Committee and ROA, ROE and ROCE.

Maina and Oluoch (2018) examines the effect of corporate Audit Committee characteristics on financial performance of manufacturing firms in Kenya. The study revealed that there exists a significant relationship between Audit Committee composition and Audit Committee meetings frequency and firms Financial Performance. In addition, Orjinta and Ikueze (2018) examined the effect of Audit Committee characteristics on performance of selected non-financial firms quoted in Nigerian Stock Exchange. A sample of 50 listed firms was used for the period 2007 to 2016. The result revealed that there is a significant positive relationship between Audit Committee independence, Audit Committee meeting and firm performance at $5 \%$ level of significant.

Nuhu, Umaru and Salisu (2017) examined the effect of Audit Committees' Quality (Audit Committee members, Audit Committee meetings and Audit Committee financial expertise) on financial performance with a focus on the Nigerian food and beverages sector. The result of the study also shows an insignificant negative effect between Audit Committee members and financial performance of the Nigerian food and beverages sector. Olayinka (2019) examined the effect of Audit Committee Effectiveness on the growth of Firms Performance in Nigeria with emphasis on Eight Public Quoted Banks in Nigeria. The findings revealed that Audit Committee size, frequency of Audit Committee's meetings and financial literacy of Audit Committee members have no significant effect on firms' performance in Nigeria.

The inconsistency in the empirical literature suggests a gap in the literature and indicates that the area is still open for further examination and that there is need for more studies to present their unique position on the issue. Given the discourse above, the aim of this paper is to empirically examine the implications of Audit Committee characteristics (Audit Committee size, independence of Audit Committee and Audit Committee frequency of meeting) on firm financial performance using selected listed firms in Nigeria. This paper is outlined as follows: literature review, methodology, results and discussion, conclusion and recommendations.

\section{LITERATURE REVIEW AND HYPOTHESIS DEVELOPMENT}

\subsection{Corporate Financial Performance}

Corporate financial performance is generally defined as a measure of the extent to which a firm uses its assets to run the business activities to earn revenues. It examines the overall financial health of a business over a given period of time and can be used to contrast the performance of identical firms in similar industries or between industries in general (Atrill, McLaney, Harvey, Jenner, 2009). The main source of data for determining financial performance is the financial statements, the product of accounting, which consists of the statement of financial position which shows the assets, liabilities and equities of a business, the income statement that records the revenues, expenses and profits in a particular period, the cash flow statement which exhibits the sources and uses of cash in a period, and the statement of changes in the owners' equity that represents the changes in owner's wealth. Financial performance of organizations' is commonly reflected in the calculation of financial ratios that show the link between numbers in the financial statements. The financial ratios may include the computation of the profitability, efficiency, liquidity, gearing, and investment of a particular firm. Moreover, firm financial performance generally may also be reflected in market-based (investor returns) and accountingbased (accounting returns) measures (Griffin \& Mahon, 1997).

Examples of market-based indicators to measure firm financial performance are price per share and Tobin's Q which indicate the market value or the share value of the firm as well as the financial prospects of the firm in the future. Additionally, what the shareholders have perceived from the returns distributed by the firm is also the driver of the share price. This price may lead to the market value of the firm. Alternatively, accounting-based measures, including profitability, efficiency, liquidity, gearing, and investment ratios, are calculated using the figures from the financial reports and may represent a firm's financial performance. According to Atrill et al. (2009), the ratios that may be utilized to calculate the firm's profitability are the return on assets (ROA), return on equity (ROE) and return on investments (ROI). These ratios express the success of a firm in generating profits or returns from the resources owned. In contrast, the market-based measure is believed to be more objective because it relies on market responses to particular decision made by a firm (Griffin \& Mahon, 1997). The choice of whether to use accounting or market-based calculations for measuring a firm's financial performance depends upon the specific aims of the research.

\subsection{Audit Committee Size and Financial Performance}

The Audit Committee size is the number of directors and shareholders that makeup the audit committees. The BlueRibbon Committee (BRC)'s report of 1990 released the usefulness of having an Audit Committee and recommended that an effective Audit Committee of listed companies should compromise of at least three directors. S. 359(4) of Companies and Allied Matters asserts that AC shall consist of an equal number of directors and representatives of the shareholders of the company subject to a maximum number of six members.

According to KMPG (2009) the size of the Audit Committee varies depending upon the needs and culture of the company 
and the extent of delegated responsibilities to the committee. The objective is to allow the committee to function efficiently and effectively. Most companies have no set policies for rotating committee members but depend on weighing a member's experience against the risk of complacency. Without a rotation policy, it is important for the board of directors to evaluate an Audit Committee member's performance to see that it meets both the board's and the committee's expectations (Mohammed, 2015). On the other hand rotation of Audit Committee members provides a practical way to refresh and introduce new perspectives to Audit Committee processes.

Ojeka, Iyoha and Obigbemi (2014) carried out a study on the influence of Audit Committee effectiveness on firm's performance. Twenty-five (25) manufacturing firms were selected and from which data were collected for the period (2004-2011). Empirical analysis was carried out and the result of the analysis showed that Audit Committee size had no significant relationship with financial performance. In another study, Gabriela (2016) examined the impact Audit Committee characteristics on firm performance using evidence from nonfinancial firms listed on London Stock Exchange in UK from 2011 to 2015. The main findings of his study suggest that there is a significant positive relationship between the audit committee size and financial performance. Premised on the foregoing, it is hypothesized that;

$\mathrm{H}_{1}$ : there is no significant relationship between audit committee size and firm financial performance

\subsection{Audit Committee Independence and Financial Performance}

The independence of the Audit Committee has been widely researched in a variety of prior studies. It has been widely argued as being one of the key characteristics associated with the effectiveness of the Audit Committee. Audit committee independence implies that its members are free from any relationship and independent from the company's management or having no relationship with any major shareholders, officers and executive directors. It is generally believed that an independent Audit Committee provides effective monitoring of the financial discretion of management and ensures the credibility of the financial statements (Kuang, 2007).

Xie, Davidson and Dadalt (2003) state that the more independent Audit Committee is, the better governance compared to less independent audit committee. Independence of audit committee helps to ensure that management is transparent and will be held accountable to stakeholders (Treadway Commission, 1987; Cadbury Committee, 1992; Blue Ribbon Committee, 1999).

Abdullah, Qaiser, Ashikur, Ananda and Thurai (2014) explored the relationship between Audit Committee characteristics, external auditors and economic value added (EVA) of public listed firms in Malaysia. The study found that Audit Committee independence is positively associated with firm performance. Orjinta and Ikueze (2018) examined the effect of Audit Committee characteristics on performance of selected non-financial firms quoted in Nigerian Stock Exchange. A sample of 50 listed firms was used for the period 2007 to 2016. The result revealed that there is a significant positive relationship between Audit committee independence and firm performance.

Consequently, the hypothesis two is stated as follows:

$\mathrm{H}_{2}$ : There is no significant relationship between audit committee independence and firm financial performance

\subsection{Audit Committee Meetings/Attendance and financial performance}

Regulators and others have expressed strong preference for an audit committee that meets frequently. Frequent audit committee meetings allow for better communication between audit committee members and auditors (both external and internal) and enable the audit committee to be more effective [The Public Oversight Board (1993), the Securities and Exchange Commission chairman, Levitt (1999) and the BlueRibbon Committee (BRC, 1999)]. The number of Audit Committee meetings is considered to be an important attribute for monitoring effectiveness (Lin, Li \& Lang, 2006). The number of Audit Committee meetings is taken as a proxy for audit committee activity (Xie, Davidson \& Dadalt 2003). As a result, the Audit Committee that meets more frequently with the internal auditors is considered better informed about auditing and accounting issues.

Ojeka, Iyoha and Obigbemi (2014) conducted a study about the influence of Audit Committee effectiveness on firm's performance. The result of the analysis showed that meetings of Audit Committee had no significant relationship with ROA. In another study, Maina and Oluoch (2018) examined the effect of corporate Audit Committee characteristics on financial performance of manufacturing firms in Kenya. This study focused on 766 manufacturing firms in Kenya for a period of 5 years, 2013-2017. The study revealed that there exists a significant relationship between Audit Committee meetings frequency and firms Financial Performance.

Thus, the hypothesis three is stated as follows:

$\mathrm{H}_{3}$ : There is no significant relationship between Audit Committee meetings frequency and firm financial performance

\subsection{Theoretical Framework}

\subsubsection{Agency Theory}

Agency theory was originated in the early of 1970s and the first scholars to propose agency theory were Stephen Ross and Barry Mitnick (Mitnick, 2006). Agency theory had been highly applied in the companies in the year 1980's because companies had the assumption which the managers are agents work on behalf of shareholders who are so called principals (Zajac \& Westphal, 2004). Accordingly, agency issue may occur due to separation of corporate management and 
ownership as the agents have control rights in the company and they may conduct opportunistic behaviors which are exploiting interests of principals (Jensen \& Meckling 1976; Fama \& Jensen 1983).

Meanwhile, Fama and Jensen (1983) asserted that agency costs have basically reduced welfare of principal, resulting in the agency problem such as the incurrence of expenses due to the incentives or monitoring of agents. Agency theory also suggested Audit Committee can strengthen their monitoring effectiveness with advanced financial and accounting knowledge by preventing corporate fraud therefore alleviating agency issue between managers and shareholders and lead to a better firm performance (Zahirul, Nazrul, \& Bhattacharjee, 2010).

\section{METHODOLOGY}

The ex-post facto research design was used in this research. Kerlinger (1970) noted that ex post facto research is one in which the independent variable or variables have already occurred and in which the researcher starts with the observation of a dependent variable or variables. The population of the study comprises of all consumer goods firms listed on the Nigerian Stock Exchange. As at the period of this study, there are about 28 of such firms (NSE, 2021). However, after filtering for firms with incomplete records, for this study coverage (which is from 2010 to 2019), only eighteen (18) firms were found with complete records. Secondary data was used for this study. The data was retrieved from corporate annual reports of the sampled firms.

\subsection{Measurement of Variables}

The variables of this study are defined and measured as follows:

i. ROA: This is defined mathematically as, profit after tax divided by total assets in line with Atrill, McLaney, Harvey, and Jenner (2009).

ii. Audit Committee size (AUDSIZE): This is the number of individuals on the Audit Committee. This approach of measuring AUDSIZE is in line with Abdellatif (2009).

iii. Audit Committee independence (AUDIND): This entails the number of independent directors on the Audit Committee. This is in tandem with the work of Xie, Davidson and Dadalt (2003).

iv. Audit Committee meetings and attendance (AUDFM): This represents the number of times Audit Committee meets in a year. This approach is in line with Lin, Li and Lang (2006).

\subsection{Model Specification}

The focus of the study is to examine the impact of Audit Committee on corporate financial performance of listed consumer goods firms in Nigeria. The models adopt those of Mahdi, Mohammad and Hossein (2018) and Olayinka (2019). The models are presented as follows;
$\mathrm{FINPERF}=f(\mathrm{AUDCX})$

Where FINPERF $=$ Financial performance measured using Return on assets (ROA)

AUDCX $=$ Audit Committee characteristics

Expanding the independent variables, we have;

$$
\begin{aligned}
& \mathrm{ROA}_{\mathrm{it}}=\partial_{0}+\partial_{1} \operatorname{AUDS}_{\mathrm{it}}+\mu_{\mathrm{it}} \\
& \mathrm{ROA}_{\mathrm{it}}=\partial_{0}+\partial_{2} \mathrm{AUDIND}_{\mathrm{it}}+\mu_{\mathrm{it}} \\
& \mathrm{ROA}_{\mathrm{it}}=\partial_{0}+\partial_{3} \mathrm{AUDFM}_{\mathrm{it}}+\mu_{\mathrm{it}} \\
& \mathrm{ROA}_{\mathrm{it}}=\partial_{0}+\partial_{1} \operatorname{AUDS}_{\mathrm{it}}+\partial_{2} \operatorname{AUDIND}_{\mathrm{it}}+\partial_{3} \operatorname{AUDFM}_{\mathrm{it}}+\mu_{\mathrm{it}}-- \\
& \text {---------- }(v)
\end{aligned}
$$

Where;

AUDIND= Audit Committee Independence,

AUDFM= Audit Committee frequency of meeting,

AUDS=Audit Committee size,

$\mu=$ Stochastic term. $\mathrm{i}=$ number of sampled cross-sectional firms, $\mathrm{t}=$ time period of the sampled companies, $\partial=$

\begin{tabular}{|c|c|c|c|}
\hline Variable & $\begin{array}{l}\text { Aprori } \\
\text { sign }\end{array}$ & $\begin{array}{c}\text { Fixed effects } \\
\text { Model }\end{array}$ & Random effects Model \\
\hline $\mathrm{C}$ & & $\begin{array}{c}0.4588^{*} \\
(0.0972) \\
\{0.000\}\end{array}$ & $\begin{array}{c}0.5713^{*} \\
(0.1012) \\
\{0.000\}\end{array}$ \\
\hline AUSIZE & + & $\begin{array}{c}0.0125^{*} \\
(0.0028) \\
\{0.000\}\end{array}$ & $\begin{array}{c}-0.0144 \\
(0.0039) \\
\{0.0003\}\end{array}$ \\
\hline ADIND & + & $\begin{array}{l}-0.0708 * \\
(0.0404) \\
\{0.0401\}\end{array}$ & $\begin{array}{l}-0.1183^{*} \\
(0.0554) \\
\{0.0330\}\end{array}$ \\
\hline AUDFM & + & $\begin{array}{l}0.1986^{*} \\
(0.0539) \\
\{0.0003\}\end{array}$ & $\begin{array}{l}0.1915^{*} \\
(0.0944) \\
\{0.0428\}\end{array}$ \\
\hline \multicolumn{4}{|c|}{ Model Parameters } \\
\hline $\mathrm{R}^{2}$ & & 0.6557 & 0.0460 \\
\hline Adjusted $\mathrm{R}^{2}$ & & 0.5318 & 0.0366 \\
\hline F-statistic & & 35.831 & 4.8538 \\
\hline Prob(F-stat) & & 0.00 & 0.00 \\
\hline D.W & & 1.9 & 1.511 \\
\hline \multicolumn{4}{|c|}{ Model Diagnostics } \\
\hline$\chi_{\text {Hetero }}^{2}$ & 0.725 & $\chi_{\text {Norm }}^{2}$ & 0.086 \\
\hline$\chi^{2}$ Serial/Corr & 0.114 & $\chi_{\text {Hausman }}^{2}$ & $20.237(0.000)$ \\
\hline $\begin{array}{c}\text { Ramsey } \\
\text { Reset test }\end{array}$ & 0.120 & & \\
\hline
\end{tabular}
beta/coefficient

The apriori signs are $\partial_{1}>0, \partial_{2}>0, \partial_{3}>0$

\section{RESULTS AND DISCUSSION}

Table 4.1: Regression Results for Audit Committee and ROA

Source: Researcher's compilation (2021) using Eviews 10.*sig @5\%,**sig @ 10\% ( ) Standard error \{ \} p-value 
As shown in the results, the $\mathrm{R}^{2}$ for the model is 0.6557 which implies that the model explains about $65.57 \%$ of the systematic variations in the dependent variable with an adjusted value of $53.18 \%$. The F-stat is 35.83 (p-value $=0.00$ ) is significant at $5 \%$ and suggest that the hypothesis of a significant linear relationship between the dependent and independent variables cannot be rejected. It is also indicative of the joint statistical significance of the model. The D.W statistics of 1.9 in the fixed effects indicate the absence of first order serial correlation in the model. The model diagnostics reveals that the $\chi_{\text {Hetero }}^{2} \mathrm{p}$-value $(0.725)$ implies the homoscedastic behaviour of the errors and the $\chi^{2}$ Serial/Corr $\mathrm{p}$ value (0.114) also reveals the absence of serial correlation. In addition, $\chi_{\text {Norm }}^{2} p$-value $(0.086)$ reveals that the series follow a normal distribution.

The analysis of coefficients reveals AUDSize is positive $(0.0125)$ and significant $(\mathrm{p}=0.000)$ at $5 \%$. The positive coefficient suggests that increase in Audit Committee size resulted in an increase in ROA. According to KMPG (2009) the size of the Audit Committee varies depending upon the needs and culture of the company and the extent of delegated responsibilities to the committee. Our findings are in tandem with Gabriela (2016) who examined the impact Audit Committee characteristics on firm performance using evidence from non-financial firms listed on London Stock Exchange in UK from 2011 to 2015. The main findings of his study suggest that there is a significant positive relationship between the Audit Committee size and its financial performance. Allam, Adel and Sameh (2013), studied impact of Audit Committee characteristics on firm performance, evidence from Jordan. The result showed that the Audit Committee has an impact on financial and stock performance. Sidiq and Krismiaji (2020) found that all of the characteristics of Audit Committee positively affect the company's performance.

On the contrary, Mahdi, Mohammad and Hossein (2018) evaluated the relationship between the characteristics of the Audit Committee and the board and profitability among the companies listed on the Tehran Stock Exchange (TSE) in Iran. The study found no significant association between Audit Committee size and corporate financial performance. Olayinka (2019) examined the effect of Audit Committee Effectiveness on the growth of Firms Performance in Nigeria with emphasis on Eight Public Quoted Banks in Nigeria. The findings revealed that Audit Committee size have no significant effect on firms' performance in Nigeria. In the same vein, Ojeka, Iyoha and Obigbemi (2014) conducted a study on the subject matter. The result of the analysis showed that Audit Committee size has no significant relationship with all performance variables.

AUDIND has a negative beta (-0.0708) and also significant $(\mathrm{p}=0.0401)$ at $5 \%$. The negative coefficient indicates that more independent boards will signal lower financial performance. The independence of the Audit Committee has been widely researched in a variety of prior studies. It has been widely argued as being one of the key characteristics associated with the effectiveness of the Audit Committee. Audit Committee independence implies that its members are free from any relationship and independent from the company's management or having no relationship with any major shareholders, officers and executive directors. It is generally believed that an independent Audit Committee provides effective monitoring of the financial discretion of management and ensures the credibility of the financial statements (Kuang, 2007). Xie, Davidson and Dadalt (2003) state that the more independent Audit Committee is argued to provide better governance compared to less independent audit committee.

This study's findings are in tandem with Gabriela (2016) which examined the impact Audit Committee characteristics on firm performance using evidence from non-financial firms listed on London Stock Exchange in UK from 2011 to 2015. The study found Audit Committee independence to be negatively correlated with firm performance. In the same vein, Bansal and Sharma (2016) examined the role of audit committee characteristics in improving firm performance. Their findings did not reveal any positive effect of Audit Committee independence on the financial performance of India firms. Aryan (2015) showed no positive significant relationship between Audit Committee composition, and companies' profitability.

On the contrary, Ojeka, Iyoha and Obigbemi (2014) explores the influence of Audit Committee effectiveness on firm's performance using independence as one of the variables. The result of the analysis showed a positive significant relationship between independence and ROA. Orjinta and Ikueze (2018) examined the effect of Audit Committee characteristics on performance of selected non-financial firms quoted in Nigerian Stock Exchange. A sample of 50 listed firms was used for the period 2007 to 2016. The result revealed that there is a significant positive relationship between Audit Committee independence and firm performance. Salisu and Nur Ashikin (2016) analysed the impact of Audit Committee attributes on the performance of finance companies in Malaysia in both period before and after the Malaysian Code on Corporate Governance (MCCG) was issued. Their findings suggest a significant positive relationship between independent Audit Committee members and profitability. Abdullah, Qaiser, Ashikur, Ananda and Thurai (2014) studied relationship between Audit Committee characteristics and economic value added (EVA) of public listed firms in Malaysia. The study found that Audit Committee independence is positively associated with firm performance.

The results showed that AUDFM has a positive beta (0.1986) and significant $(\mathrm{p}=0.0003)$ at $5 \%$ which implies that higher number of Audit Committee meeting will have a positive and significant impact on financial performance. The number of Audit Committee meetings is considered to be an important attribute for monitoring effectiveness (Lin, Li \& Lang, 2006). 
The number of Audit Committee meetings is taken as a proxy for Audit Committee activity (Xie, Davidson \& Dadalt 2003). As a result, the Audit Committee that meets more frequently with the internal auditors is considered better informed about auditing and accounting issues. An Audit Committee that meets frequently can reduce the possibility of financial fraud (Abbot, Parker \& Peters, 2004; Raghunadan, Rama \& Scarbrough, 1998). Bryan, Liv and Tiras (2004) posited that Audit Committees that meet regularly are often expected to be able to perform monitoring tasks more effectively than others that do not meet regularly.

This study's findings are supported by Maina and Oluoch (2018) revealed that there exists a significant relationship between Audit Committee meetings frequency and firms Financial Performance. Nuhu, Umaru and Salisu (2017) results revealed a significant positive effect between Audit Committee meetings, and financial performance. Orjinta and Ikueze (2018) result revealed that there is a significant positive relationship between Audit Committee meeting and firm performance at 5\% level. Gabriela (2016) findings observed that there is a significant positive relationship between frequency of meetings and its financial performance. On the contrary, the work of Ojeka, Iyoha and Obigbemi (2014) found that meetings of Audit Committee have no significant relationship with all performance variables. In the same vein, Bansal and Sharma (2016) study did not reveal any additional effect of Audit Committee meeting frequently on the financial performance of India firms.

\section{CONCLUSION AND RECOMMENDATION}

Undeniably, the existence of an appropriately constituted Audit Committees is now a necessity for all listed companies in Nigeria with corporate governance regulation placing significant importance on the role of Audit Committee. Audit Committees have been widely recommended around the world as an important mechanism for improving the quality of the company's financial reports (Blue Ribbon Committee, 1999). Audit Committee is an important and necessary monitoring mechanism widely used in worldwide corporate organizations to monitor the financial reporting process and strengthen corporate governance.

The aim of this study was to empirically examine the implications of Audit Committee characteristics on firm financial performance using selected listed firms in Nigeria. Particularly, the study looks at the role of audit committee size, Audit Committee frequency of meeting and Audit Committee size. Findings reveal that Audit Committee meetings frequency has a significant effect on financial performance of selected listed Nigerian companies. Also, independence of Audit Committee members has a significant effect on financial performance of selected listed Nigerian companies. In addition, Audit Committee size has a significant effect on financial performance of selected listed Nigerian companies.
In line with the study's findings, the following recommendation was made. Firstly, there is the need to increase the level of Audit Committee independence as more independent members will ensure greater objectivity, monitoring and transparency. Secondly, there is also the need for audit committees to meet more frequently as this will also improve their monitoring capacity. Thirdly, though current corporate governance codes in Nigeria seem to ensure that Audit Committee size is not less than six, there may be several companies that have below this number. Hence there is need to check compliance by companies even though the size of the Audit Committee may also be influenced by several other factors.

\section{REFERENCES}

[1] Abdellaltif, A. E. M. (2009). Corporate governance mechanism and asymmetric information: An application on the UK Capital Market. (Unpublished PhD thesis), University of Surrey, U.K.

[2] Abdullah, A., Qaiser, R., Ashikur, R., Ananda, W., \& Thurai, M. N. (2014). Relationship between audit committee characteristics, external auditors and economic value added (EVA) of public listed firms in Malaysia. Corporate Ownership \& Control, 12, 900-. $\quad 10.22495 /$ cocv12i1c9p12.

[3] Allam, H., Adel S., \& Sameh, R. (2013). The impact of audit committee characteristics on the performance: Evidence from Jordan. International Management Review. 9. 32-42. $10.2139 / \mathrm{ssrn} .3648194$.

[4] Aryan, L. A. (2015). The relationship between audit committee characteristics, audit firm quality and companies' profitability. Asian Journal of Finance \& Accounting, 7(2), 215226.

[5] Atrill, P. (2006). Audit committee, Finance Matters, 14. Atrill, P., McLaney, E., Harvey, D., \& Jenner, M. (2009). Accounting: An introduction.

Edition, Pearson Education, Australia.

[6] Bansal, N., \& Sharma, K. (2016). Audit committee, corporate governance and firm performance: Empirical evidence from India. International Journal of Economics and Finance 8(3), 103-116.

[7] Blue Ribbon Committee (1999). Report and recommendations of the Blue Ribbon Committee on improving the effectiveness of corporate audit committees. The Business Lawyer, 54, 106-1095.

[8] Bryan, D. M., Liv, H. C., \& Tiras, S. 1. (2004). The Influence of independent and effective audit committee on earnings quality. Working Paper, State University of New York, Bufallo.

[9] Cadbury Committee (1992). Report of the committee on the financial aspects of corporate governance: A code of best practice, London.

[10] Carter, D. A., Simkins, B. J., \& Simpson, W. G. (2003). Corporate governance, board diversity, and firm value. Financial Review, 38(1), 33-53. https://doi.org/10.1111/1540-6288.00034

[11] Corporate Governance Code of Nigeria (2010), Lagos.

[12] Enofe, A. O., Aronmwan, E. J., \& Abadua, H. S. (2013). Audit committee report in corporate financial statements: Users' perception in Nigeria. European Journal of Accounting Auditing and Finance Research 1(1), 16-28.

[13] Fama, E. F., \& Jensen, M. C. (1983). Separation of ownership and control. Journal of Law and Economics, 26(2), 301-325.

[14] Gabriela, Z. (2016). The Audit Committee Characteristics and Firm Performance. Unpublished dissertation, master in finance, UK.

[15] Griffin, J., \& Mahon, J. (1997). The corporate social performance and corporate financial performance debate: twenty-five years of incomparable research. Business \&amp Society. 36. 5 - 31. 10.1177/000765039703600102. 
[16] Iswatia, S., \& Anshoria, M. (2011). The Influence of Intellectual Capital to Financial Performance at Insurance Companies in Jakarta Stock Exchange (JSE). Proceedings of the 13th Asia Pacific Management Conference, Melbourne, Australia.

[17] Jensen, M., \& Meckling, W. (1976). Theory of the firm: Managerial behavior, agency costs, and ownership structure. Journal of Financial Economics, 3(6) 305-360.

[18] Kerlinger, F. (1970). Foundations of behavioural research. New York: Holt, Rinehart and Winston, Inc.

[19] Kuang, C. (2007). Audit committee characteristics and earnings management. A dissertation submitted to Auckland University of Technology, New Zealand

[20] Levitt, A. (1998). The Number Came' Securities and Exchange Commission. NYU Centre for Law and Business, New York.

[21] Lin, P., Li, H., \& Yang, E. (2006). The auditor's going-concern decision: Some UK evidence concerning independence and competence. Journal of Business Finance \& Accounting, 20(2), 213-228.

[22] Mahdi, S., Mohammad, T., \& Hossein, T. (2018). The effect of characteristics of audit committee and board on corporate profitability in Iran. Journal of Economic and Administrative Sciences, 34(1), 71-88

[23] Maina, L. K., \& Oluoch, O. (2018). Effect of corporate audit committee characteristics on financial performance of manufacturing firms in Kenya. International Journal of Social Sciences and Information Technology, 4(10), 684-701

[24] Mitnick, B. M. (2006). Origin of the theory of agency: an account by one of the theory's originators. Unpublished doctoral dissertation, University of Pittsburgh, Pittsburgh, Pennsylvania, United States.

[25] Mohammad, A. J. (2015). Audit committee characteristics improving financial reporting quality among Malaysian listed company. European Journal of Social Science Review, $1(2), \quad 18-28$

[26] Mustafa, M. (2012). Audit committee and financial reporting. Business and Management Review, 2(20), 52-61.

[27] Naser, K., \& Mokhtar, M. (2004). Determinants of Corporate Performance of Malaysian Companies. Fourth Asia Pacific Interdisciplinary Research in Accounting Conference, 1 (1), 16-25. Singapore.
[28] Nuhu, M. S., Umaru, S. Y., \& Salisu, S. (2017). The effect of audit committee's quality on the financial performance of food and beverages industry in Nigeria. International Journal of Business and Management Invention (IJBMI), 6(9), 32-40.

[29] Ojeka, S. A., Iyoha, F. O., \& Obigbemi, I. F. (2013). Audit committee characteristics and firm financial performance in Nigeria. International Business Information Management Association Conference, Rome, Italy.

[30] Okoi, I., Stephen, O., \& Sani, J. (2014). The effects of corporate governance on the performance of commercial banks in Nigeria. International Journal of Public Administration and Management Research (IJPAMR), 2(2), 219-234

[31] Olayinka, O. (2019). Audit committee and firm's performance in Nigeria: Case study of selected Nigerian Banks. International Journal of Scientific and Research Publications

(IJSRP). 9, 9315. DOI: 10.29322/IJSRP.9.09.2019.p9315

[32] Orjinta, H. I., \& Ikueze, N. E. (2018). Effect of audit committee characteristics on performance of non-financial firms: Evidence from a recessed economy. International Journal of Innovation and Applied Studies, 24(1), 289-298

[33] Salisu, K. B., \& Nur-Ashikin, M. S. (2016). Audit committee attributes and firm performance: Evidence from Malaysian finance companies. Asian Review of Accounting 23(3), 206-231

[34] Sidiq, A., \& Krismiaji, K. (2020). Audit committee characteristics and financial performance: Indonesian evidence. Equity. 22. 139. 10.34209/equ.v22i2.1326.

[35] Treadway Commission. (1987). Report of the national commission on fraudulent financial reporting. American Institute of Certified Public Accountants. New York.

[36] Xie, B., \& Davidson, W. \& Dadalt, P. J. (2003). Earnings management and corporate governance: the role of the board and the audit committee. Journal of Corporate Finance, Elsevier, 9(3), 295-316,

[37] Zahirul, M., Nazrul, M., \& Bhattacharjee, S. (2010). Agency problem and the role of audit committee: Implications for corporate sector in Bangladesh. International Journal of Economics and Finance, 2(3), 177-188.

[38] Zajac, E. J., \& Westphal, J. D. (1994). The cost and benefits of managerial incentives and monitoring in large U.S. corporations: When is more not better? Strategic Management Journal, 15(1), 121-142 